\title{
Simulation based teaching of paramedics in endotracheal intubation: a mannequin study
}

\author{
Malene Schou Nielsson", Jacob Madsen, Per Henrik Lambert \\ From Danish Society for Emergency Medicine: Research Symposium 2010 \\ Roskilde, Denmark. 20-21 May 2010
}

\section{Background}

Previous studies have shown a steep learning curve in endotracheal intubation using the $\operatorname{Airtraq}(R)$ for non skilled personnel. We examined 16 Danish paramedics' ability to intubate by using the $\operatorname{Airtraq}(\mathrm{R})$. The paramedics went through a 1-day course at CeMS (Centre for Medical Simulation, the department of Anaesthesia, Aalborg, Denmark) with skill training and simulation based teaching with the Airtraq(R). The objective of the course was that the paramedics should be able to intubate in less than 30 seconds.

\section{Methods}

A mannequin study with skill training. The skill training was divided into a basic part of practice on a Laerdal(R) Airway Management Trainer and an advanced part of practice on two different mannequins (Meti HPS(R) and AIRSIM multi(R) with five attempts to intubate on each mannequin. We observed and registered two time measureing points $(\mathrm{A}+\mathrm{B})$; $\mathrm{A}$ indicating the time spend from opening the Airtraq( $R$ ) to endotracheal intubation registered by thorax movements, $B$ indicating in seconds the time spend from the Airtraq(R) passing the mannequin tooth row to secure placement of the endotracheal tube. failed attempts of intubation. All attempts resulted in successfully endotracheal intubation.

\section{Conclusion}

This mannequin study has shown that Danish paramedics are able to learn how to intubate using the Airtraq (R) on three recognized mannequins designed for skill training in intubation. The objective of the course was them being able to intubate using the $\operatorname{Airtraq}(R)$ in less than 30 seconds, which they fulfil. The median intubation time declines throughout the attempts of intubation, indicating a steep learning curve as previous studies have shown for non skilled personnel using the Airtraq. Also this study has shown that skill training in general increases the individual performance.

Published: 17 September 2010

doi:10.1186/1757-7241-18-S1-P29

Cite this article as: Nielsson et al: Simulation based teaching of paramedics in endotracheal intubation: a mannequin study.

Scandinavian Journal of Trauma, Resuscitation and Emergency Medicine 2010 18(Suppl 1):P29.

\section{Results}

The median time for intubation on Laerdal(R) Airway Management Trainer is as follows (time B): 1st attempt: 49,00 sec., 2nd attempt: 35,50 sec., 3rd attempt: 34,00 sec., 4th attempt: $25,00 \mathrm{sec} ., 5$ th attempt: $22,50 \mathrm{sec}$. The median time in advanced practice was less than 30 seconds, except the first attempt on METI HPS, which was 45,50 sec. The 5th attempt of intubation on METI HPS and AIRSIM multi was respectively 19,00 and $17,50 \mathrm{sec}$. There were no

\footnotetext{
* Correspondence: mascn@rn.dk

Depatment of Anaesthesia and Intensive Care Medicine, Aalborg hospital, Århus University Hospital, Aalborg, Denmark
}

Submit your next manuscript to BioMed Central and take full advantage of:

- Convenient online submission

- Thorough peer review

- No space constraints or color figure charges

- Immediate publication on acceptance

- Inclusion in PubMed, CAS, Scopus and Google Scholar

- Research which is freely available for redistribution

Submit your manuscript at www.biomedcentral.com/submit
Biomed Central 